(e-migrinter

e-Migrinter

$5 \mid 2010$

Migrations dans les pays nordiques

Communicative competence and its importance for integration in a multicultural school in rural Norway

Ane Sætha

\title{
CpenEdition
}

Journals

Electronic version

URL: https://journals.openedition.org/e-migrinter/2022

DOI: 10.4000/e-migrinter.2022

ISSN: 1961-9685

Publisher

UMR 7301 - Migrinter

Printed version

Date of publication: 28 April 2010

Number of pages: 24-35

ISSN: 1961-9685

Electronic reference

Ane Sætha, "Communicative competence and its importance for integration in a multicultural school in rural Norway", e-Migrinter [Online], 5 | 2010, Online since 20 April 2020, connection on 20 May 2021 URL: http://journals.openedition.org/e-migrinter/2022 ; DOI: https://doi.org/10.4000/e-migrinter.2022 


\section{Communicative competence and its importance for integration in a multicultural school in rural Norway}

Ane Sætha

$\mathbf{I}$

$\mathrm{n}$ the $19^{\text {th }}$ and early $20^{\text {th }}$ century many Norwegians migrated to North America. In early 1960s, however, the trend had turned, and during the last 30 years Norway has gradually become more diverse in terms of culture and religion. Norwegian politicians, amongst others, believe this has challenged the traditional thoughts of Norway as a culturally homogenous society, and these new challenges and possibilities are creating new cultural impressions (Stortingsmelding ${ }^{1}, 30$, $2003 / 2004$, ch. 3). By the beginning of 2004, 7,6 \% of the population in Norway were immigrants, $30 \%$ of these came from the western world (Statistisk Sentralbyrå $\left.^{2}, 2004\right)$.

\footnotetext{
1 Parliamentary reports. These are reports from the government to the parliament, and contains suggestions and recommendations from various ministries.

2 Statistics Norway http://www.ssb.no/english/.
}

Introduction $^{3}$

In the last few years, many parliamentary reports have focused on the increasing plurality and two points seems to be of special importance : first, it is about a multicultural society and how a society like this ideally should be. Second it is about language literally, i.e. about Norwegian language and mother tongue teaching (Stortingsmelding, 17, 1996/1997 ; 25, 1998/1999 ; 30, 2003/2004, 49, 2003/2004).

The parliament reports, the national teaching plans and different public reports focus on the nature of an ideal society, and don't say anything about how to achieve it. Most politicians believe in decentralizing, so a lot of the asylum centers in Norway are placed outside the main cities, or in rural districts. The number of asylum centers varies, depending on the need but usually between 100 and 150 during the last few years that are connected to the Norwegian Directorate of Immigration.

When it comes to integration, politicians take it for granted that a decentralizing policy is important, and that the schools are one of the most important institutions to achieve it. They assume that equality and knowledge about language will solve all problems ; and equality in all areas in the society is quite simple, namely one only has to know about each other's "culture" and respect it. The focus on language is only language literally, that is, only the language in itself and not other

\footnotetext{
3 This article is based on fieldwork conducted during August to December 2003 as a part of masters degree in social anthropology at the University of Copenhagen.
} 
forms of communications, which are also culturally specific.

The anthropological perspective on linguistic competence is not only about language in itself. It is about language as well as cultural competence (Lidén 2000: 217; Moldenhawer 2002). The term linguistic competence includes therefore not only knowledge of language itself but also understanding the nuances and the complexity in different contexts and relations, or in other words : being able to read cultural codes, purposes and meanings. Interacting with others means learning physical competences and ways of behavior as well as verbal negotiating, and interpreting what is going on (Lidén, 2000 : 26 ; Thorseth, $1995: 163 \mathrm{ff})$. Therefore it is better to use the term "communicative competence" instead of linguistic competence (Gullestad, 2002 : 70).

Spoken language is an important part of communicative competence and the children who don't have the power of words embodied will have more difficulties in an interaction with other children (Bundgaard and Gulløv, 2003 ; Lidén, 2000 ; Lidén, 2001: 68ff ; Palludan, 2002 ; Thorseth, 1995 : 13ff). Those who cannot express themselves with words have to communicate with actions. Pupils who are good at oral communication might also get more positive attention from teachers because these pupils' reflections and relational competence are preferred and appreciated by the adults (Lidén, 2000 : 192). They will also automatically be able to take "the lead" over the others by being looked up to. The ability to take part in interaction and to know the social codes also have an impact on learning language (Lidén, 2000 : 179ff ; Moldenhawer, $2002: 20$ ).

\section{Integration}

Integration is an ambiguous idea that varies with different people and in different situations (Seeberg, 2003 : 49). Preis has said that integration is similar to culture in the sense that it is impossible to define, and that everybody has an opinion on it (Preis, 1998 : 11). Some emphasize cultural factors, some stress social factors, others see integration as a joint term for various concrete initiatives (Ejrnæs, 2002 : 7). A common way to describe integration in public space is to put it in between the ideas of assimilation and segregation as a kind of compromise between these (Emerek, 2003 ; Preis, 1998 : 13 ; Skovholm, 1998 : 54 ; Stortingsmelding, 17, 1996/1997 ; 49, 2003/2004; Wikan, 2002 : 71). Both assimilation and segregation are associated with something negative, but integration becomes something positive : "the golden mean". Linking these three terms together give them a predestined and set content, and contributes to keep up the ambiguity of the idea (Preis, 1998 : 13 ; Skovholm, 1998 : 54).

In discussions about ethnic minorities, the idea of integration is often used as a "model" for the kind of adjusting that is assumed to be ideal. This can be problematic as the notion could have different meanings in different surveys and situations (Ejrnæs, 2002 : 54). According to a Norwegian thesaurus the word "integrate" is synonymus with, amongst others: coordinate, harmonize, synchronize. These terms indicate that "what or who is to be integrated' is juxtaposed with 'to what or who is integrated' into.

The teachers at the field school defined integration as when a pupil with a different cultural background [other than Norwegian] is acknowledged and is able to take part in the school environment without necessarily becoming alike the other pupils at the school [...] The pupil must get the opportunity to understand berself as a minority individual in a multicultural world (Sætha, 2006). ${ }^{4}$ According to this, it seems that the minority pupils are integrated when they in some situations are homogenous to the majority pupils and in other situations are different. The question

\footnotetext{
${ }^{4}$ My translation from Norwegian.
} 
is, however, how "homogenous" or how "different" the pupils have to be (Gullestad, 2001, $2002: 19,79 \mathrm{ff}$ ), in which situations they have to be "homogenous" or "different", who decides what is "homogenous" and what is "different", and who decides the contexts. The school class system have a lot of implicit and explicit cultural rules for behavior which makes integration of minority pupils in schools a complicated and long process. Some of the implicit rules cannot be explicitated and are therefore difficult to discover for outsiders (Anderson, $2000: 236,253 \mathrm{f}$ ). The minority pupils do not only have to learn the majority language - Norwegian in this case - but they also have to learn to use it in all situations, and they need to learn the explicit and implicit codes, norms and rules for playing and behavior.

\section{The ideology of likeness}

The idea of likeness is widespread, at least in Scandinavia, and is important for the national self-understanding for many people. The term "likeness" has many meanings, the most common is to divide between "equality" and "homogeneousness" (Gullestad, 2001 : 35, 2002 : 68f). Homogeneousness involves for instance being similar as human beings, to look alike ; ignore differences; or wearing the same dress. Equality implies amongst other things that everyone has the same opportunities and possibilities for example to be different, and it contains social equalization and "result-likeness" where the weakest are compensated. The ideal of likeness involves that one has to feel homogeneous to "everybody else" to "fit" together (Gullestad, 2002 : 68f, 82 ; Seeberg, 2003 : 25ff). Seeberg means that in Norway, likeness is a necessary starting point for interaction between people (Seeberg, 2003 : $27,186)$. In the same time, it's important to remember that there's nothing which is absolutely homogeneous or absolutely different, this is something which is culturally decided and usually it's the majority population who has the power of deciding what is homogeneous and what is different.

The ideology of likeness entails that what people have in common will be emphasized while the differences, the social borders, will be de-emphasized. Only when a definition of the situation is established, the differences will be taken out for the individual to "confirm herself" (Gullestad, 2001 : 35ff ; 2002 : 82ff ; Barth, 1998). This implies that one sees different social groups as "the others", as different or as "strangers" in relation to oneself (Barth, 1998 : 15). In the same time identification of "others" is an important element in establishing one's own identity (Eriksen, 2002 : 89). Generally speaking one can say that social identity is most important at the moment were it seems threatened (Eriksen, 2002 : 68). Gullestad's term "borders of likeness" is central in this case, because the term includes the distinctions and power-balance that the demands of likeness often require and maintains (Gullestad, 2002 : 84). Differences are often perceived as problems but paradoxically they are created in order to strengthen the likeness and the belongingness inside a group (id. ibid.).

One step further from Gullestad's "borders of likeness" is Eriksen's "paradox of multiculturalism" (Eriksen, 2002 : 144f). Eriksen means that on the one hand the majority population says that the minority has to become homogenous with the majority in order to take part in the society, and on the other hand it says : No matter how much like us you are, you will remain apart (Eriksen, 2002 : 144 ; Gullestad, 2002 : 102f ; Thorseth, 1995). The first is a matter of assimilation hidden by the ideology of likeness, the latter is a question of segregation. This shows that the differences, which according to the "borders of likeness" are needed for likeness to exist, really exist. 
The field

$\mathrm{Dal}^{5}$ is the centre of the municipality in southern Norway that had approximately 6100 inhabitants scattered over $1190 \mathrm{~km}^{2}$ at the time of the fieldwork. There are several small centers around in the municipality, but the majority of the inhabitants live within a $10 \mathrm{~km}$ radius of the municipality centre. Dal municipality has a relatively ethnically homogenous group of inhabitants. However, in the last few years the number of minority families has increased : 1,6 \% of the population were immigrants from nonwestern countries. In comparison, the corresponding fraction for Oslo was 17,6 \% (Statistisk sentralbyrå, 2004). In Dal municipality about one fifth of the workforce was engaged in farming and forestry ${ }^{6}$. There are several farms also in the centre of Dal, and most of the pupils at the school either lived on a farm or had close friends living on a farm at the time of the fieldwork. Another relatively large sector is service, where about one third of the population is working. More than half of the geographical area of the municipality consists of mountains and forests which are accessable to everyone, and they are much used both by the locals and tourists.

In Dal there is also an asylum centre, established in May 2002, in accordance with the government's decentralizing policy. The children at the asylum centre between 6 and 12 years old went to Flata School. At the time of the fieldwork (autumn 2003) the asylum centre had 130 inhabitants from 19 different countries : 10 to 12 of them went to Flata School, some went to the secondary school and some to the high school. The field school had approximately 180 pupils spread from $1^{\text {st }}$ to $7^{\text {th }}$ year ${ }^{7}$ (6 to 12 years

\footnotetext{
${ }^{5}$ All names of people and places are made up and do not have any connection with the real people and places.

${ }^{6}$ All statistics about the municipality is found on the municipality's own internet homepage and on Statistisk Sentralbyrå http://www.ssb.no.

7 Here each year will be called "age-class" to distinguish it from "World class".
}

old). The focus for this article is mainly on year 6 which had 16 boys and 11 girls. Two of these, Khalid and Sogan, were permanently resident minority pupils. In addition, 4 minority pupils from the asylum centre were connected to the class throughout the autumn. Jelena, Irina, Arta and Amin, but only Jelena was present during the whole fieldwork.

The school had created something called the "World class". This is where the minority pupils learned about Norway and the Norwegian language. Some of the permanent minority pupils spent some hours there, depending on their Norwegian skills. The new children from the asylum centre spent most of their days in this class, only being with their "age-class" in classes like cooking or PE (Physical Education) or maybe music. The World class teacher and the "age-class" teacher decided when a World class pupil was ready for their "ageclass" also in theoretical subjects.

\section{Discussion}

The society ${ }^{8}$ and most people like to see the school as a key to integration, or they expect it to be, that is, integration when it comes to ethnicity. This expectation puts an enormous pressure on the school. The school can, as a consequence of this pressure be overwhelmed by the enormous task, and the lack of resources, economic, professional and spatial, will be even more obvious. According to the society, integration includes equality in status and opportunities in the community and it's the school's task to teach the pupils this, both directly and indirectly (L-97 ${ }^{9}$; NOU? 1995 : 12 ; Stortingsmelding? 30 2003/2004; 49 2003/2004). The teachers' definition of integration emphasizes recognition of each other and relational competence in the school environment. It also indicates that a minority pupil should be able to both belong to "us" and to "them". This means that she

\footnotetext{
8 That is, in this case the official, political Norway.

9 The latest national teaching plan.
} 
should be able to function together with the majority pupils at the same time as she keeps her "national identity" (Sætha, 2006). These ideals were difficult to reach in practical life, amongst other things because of a constant change of minority pupils.

When children learn to speak they learn not only the grammar of how to make a sentence but also cultural norms regarding when you can speak or do something and when one shouldn't; what one can talk about, with whom, where, when and in what way. This also holds good for knowledge on how to behave for example at the playground (Duranti, 2002 : 20 ; James, 1993 : 159ff ; Sjögren, 1995 : 316 ; SkutnabbKangas, 1986 : 38 ; Moore, 1993). This is also called implicit knowledge. It's the same when learning a new language ; it's not always enough to learn the language itself. Someone new to a place might become an outsider if he or she doesn't know the common frames of references. She can't take for granted what she knows and will often need extra explanations (Lidén, 2000 : 217 ; Anderson, 2000 : 253f).

Communication always involves the risk that the receiver gets a different understanding of the message than the sender meant it to be (Qvortrup, 2002 : 142ff). The same action can therefore be interpreted within several frames of references. This is connected to the fact that experience and reality is individual and subjective, and is not only due to the individuals different experiences (Bruner, 1986 : 5). Language is a symbolic way of perceiving reality, and not a reflection of reality (Gulløv, 1999 : 193). Information and meaning only grows in a process where listeners, readers or viewers analyze what they hear or see ; meaning is not "extracted" but constructed. The same text can be analyzed differently in different contexts and depending on the person interpreting (Chandler, 2000 ; Bostad, 1998). As Wikan (1993 : 191f) says : truths are made rather than found, because all vocabularies are man-made, they do not "fit" the world (...) most of reality is indifferent to our descriptions of it. The world does not speak. Only we do. Everything one does is communication, one cannot notcommunicate (Qvortrup, 2002 : 162f). All ones movements with one's body or sounds are communication and are analyzed by the receivers consciously or subconsciously.

Children use their own experiences picked up from different situations, to put together relations, concepts and practices (Lidén, 2000 : 32 ; 2001: 68ff). All the minority pupils at the field school learned by copying the majority pupils - that was very obvious with, for example, Khalid in class. Sometimes he would directly and precisely copy some of the boys, both words and movements. But he would only copy those that he thought of as the "coolest". Some signals, however, he didn't discover. For example when they chose groups in the newspaper project. They had to choose which section they wanted to work on and Khalid didn't realize that some "horse girls" wanted the sports section and that the other boys therefore were going to select something else. First he raised his hand for sports, because he assumed that the "cool boys" would choose this. He withdrew fast when he discovered that he was the only boy and did not sign up for anything until he saw that several other boys - and no girls - did the same.

Khalid had to play safe. He wanted to be accepted as one of the "cool" boys in class, but he had to be careful because a wrong step meant he would most likely be teased about it. So he tried to copy as exactly as possible. Problems with pronunciation or special codes, as above-mentioned example, are examples of the fact that the minority pupils don't have the power of words, something one can also call linguistic impotence. Khalid spoke Norwegian well, but was teased because he didn't pronounce everything 100\% correctly, for instance some Norwegian names and rhymes, as he 
had problems with some sounds in the Norwegian language.

For the ethnic Norwegian pupils in general, integration involved being able to speak "proper" Norwegian, and to be "kind". Speaking Norwegian well and behaving "Norwegian" was apparently more important than, for example, looks. Even though I didn't interview any of the minority pupils specifically, it was obvious that they understood the necessity of acquiring the behavior of the majority to be "accepted". Both the definitions of integration given by the teachers by the Flata school and from the L-97, take it for granted that it's the minority pupils that have to integrate and adapt. In other words, a critical multiculturalism (Turner, 1993 ; Gullestad, 2002 : 302; Seeberg, 2004 : 220) doesn't work in practice at school, because the starting point of this kind of multiculturalism is to look at cultural differences as a necessary basis to construct a central, open and democratic common culture. This can be done by challenging and adapting both the minority's and the majority's, attitudes and principles.

In the minds of the majority pupils, spoken language was very important when it came to the relations between the majority and the minority pupils. It is interesting that the majority pupils put linguistic competence and "kindness" as two sides of a coin. If one speaks "good Norwegian" one is "kind" and if one cannot speak "understandable" or "good" Norwegian one is not "kind". The ethnic Norwegian pupils told me this explicitly. When asked directly about how it would have been if everyone had spoken "perfect" Norwegian, Maja answered quickly that then they would have been much kinder. That is also why the pupils found Jelena was mean ; because she didn't speak Norwegian very well. Irina, on the hand, was kind because they understood her Norwegian and she understood theirs. Jenny said: ....we don't understand what Jelena says, but we understand what Irina says, she is very kind.
James connects language and identity by saying language is an emblem of groupness (James, 1995 : 43ff). With that she means it is a sign of belonging to a special group. But one has to understand, and be able to use the language correctly in order to belong to the group. Language as belongingness could be important for instance in homogenous groups : among children with the same ethnic background or among children who would like to belong to a specific group. But this is only one way to see it. As James also implies, language can at the same time create distance, for instance if someone is held outside a group because of language one way or other.

We see from the above-mentioned example that there is a clear connection between language and belongingness. The explanation the majority pupils gave for this combination of linguistic competence and degrees of kindness, is that if the minority pupils understand what the majority pupils say, there will be less misunderstandings, and "they" will stop "hitting and kicking". This can be compared to one of Seeberg's informant's statements : One acts Norwegian, one doesn't look Norwegian (Seeberg, 2003 : 94). That is, if the minority pupils do as the ethnic Norwegian pupils do, they act "Norwegian" even though they do not necessarily look "Norwegian".

This also agrees with Lidén's findings. Somewhere she says that differences in position is not explained by external symbols like clothes but with the fact that the minority pupils don't have the "obvious" knowledge that the majority pupils have (Lidén, 2001 : 77; see also Lidén 2000). According to Lidén, it is, in other words, first and foremost language, and secondly other cultural symbols and competences that are important for the majority pupils' cooperation and relations with the minority pupils.

The question now is which other factors than language itself are important. 
There were several things, for example belongingness to place, and skin color. Some pupils thought that skin color was important for friendship and relations. But it turned out that those who believed this called all the minority pupils "brown", no matter if they had another skin color or not. I interpreted this to mean that it wasn't the skin color in itself that was the "problem" but first and foremost the difference in language and in the way of behaving. I based this conclusion on observations of pupils who were adopted by ethnic Norwegian parents. Such adopted pupils who had another skin color than white were not called "brown".

Sondre: ... we don't want... brown ones here...

Rita: Shh...

Me: But Jelena isn't brown?

Sondre: No!

Agnete: No, but Jelena is kind of a little... she's a little meaner, she's a little meaner. She doesn't speak Norwegian and she...she is kind of a little rejecting...

The importance of language for friendship and belongingness was in this way very clear. This can also be illustrated with the following interview with Jens and Daniel:

Me: How would it be, for example outside during the breaks, if all the $W$ orld class pupils spoke fluent Norwegian?

Jens: ...it would have been a bit different but...yeah... II] wouldn't have been so much with them if they hit and kick and stuff...

Daniel: Noo...don't really think they would start attacking us if they had understood what we had said and stuff...

The boys generalize and one gets the impression that all the World class pupils are very aggressive using "hits and kicks" when in fact only very few once in a while took to action when their vocabulary was insufficient. But it also needs to be mentioned that the minority pupils' actions were not necessarily the first action, and if it was, it was most likely directly provoked. Jens thought things would have been different if everybody spoke Norwegian, but, as he said, it wouldn't help if they still "hit and kick". He said, in other words, that it is not unbelievable or "unnatural" that they "hits and kicks" no matter what. Daniel connected language and behavior and thought that if they can speak and understand Norwegian, they would stop "hitting and kicking". He believed behavior and ways of being arrives naturally from linguistic competence. It is not clear, however, if Jens and Daniel thought that to "hit and kick" is natural for the minority pupils because they are "non-Norwegian".

If the minority pupils came across a situation with the majority pupils or with the teachers which they didn't like or couldn't handle, they often played on lack of linguistic competence to get out of the situation. They could for example say "I don't understand" or just nod or shake their head. One of the teachers said that Sogan wanted to hide the fact that she was different from the others or that she didn't have the "obvious" knowledge by not saying anything at all. For example, she chose to work alone instead of in groups if she had a choice. And one day she came a bit late to her "age-class", she sat down and started doing some exercises from the World class, so that everyone could see she didn't need special help, and therefore she wasn't any different from them. Sogan has in this case the cultural capital (Bourdieu, 1986 \& 2003) that is needed to show she is homogenous with her class mates. She has found out that at this school, language and behavior is more important than looks and clothes, and she's proving her competence by doing as the other girls : she sits quietly down and works on something. She doesn't show that she is insecure as to which subject they have or what the others do, she wants to give the impression that she knows what is going on. 


\section{The importance of the local environment}

Belongingness to a place is an important symbol for an individual identity. Both Kramer and Gullestad (Seeberg, 2003 : 86f) argue that local belongingness in Norway is a national symbol and the base for defining a Norwegian identity. This belongingness is based on origin, i.e. historically to where and to whom one can draw the ancestral lines (Gullestad, 2002 : 64). On this background Kramer thinks that this makes it impossible for "strangers" to be accepted as Norwegians (Seeberg, 2003 : 86f).

A family with roots in Dal has a large network in the local environment which has existed longer than the existing members of the family. Even those who do not personally know every inhabitant, often know name, position and maybe even the family history to most of the "natives". In bigger cities like Oslo where more people are highly mobile, a family's network is usually smaller and more likely to be based on acquaintances and relations rather than history.

A relatively small place like Dal is characterized by transparency and the inhabitants are likely to encounter several of an individual's many roles. For example the teacher can be both a neighbour and a friend of the family. For the pupils at Flata school this means that their class-mates are also their playmates off school, privately and in organized activities. Some of the organized spare-time activities the pupils in class 6 were involved in, however, also included some children from other schools in the municipality and were more mixed in age. When asked about friends, all the boys gave similar answers, here with Daniel's words : ...all the boys and...some of the girls [in the class]. In their spare time the boys mentioned those that lived the closest as playmates. The girls on the other hand answered the usual relations, mostly pairs, but occasionally a group of three or four.
They also stuck together in their spare time no matter where they lived.

Most of the world class pupils stayed at the asylum centre in Dal, something that in itself gave them a very weak position at the school. Outside the teacher's hearing, these pupils was often called simply the "asylum seekers" with a touch of derogatory tone, by the ethnic Norwegian pupils. Because the minority pupils at the asylum centre or the other minority pupils could not base their presence at the school by belongingness to the place, neither local nor national, they had to "prove" to the majority pupils that they "fit" in, that they were "homogenous". But at the same time they wanted to stress that they were slightly different. Not even the minority pupils who were permanent residents were looked upon as a part of "us" by the locals, even though their Norwegian was good.

The "locals", in this case the majority pupils and the teachers, decided what it means to be "homogenous", in their position as majority and by means of belongingness to the place. By being conscious that they belong to the dominant group they became more confident because they knew they had the rest of the majority on their "side", and therefore the dominance got strengthened (see Seeberg, 2003 : 35). Due to the small number of minority pupils, they neither set the agenda nor decided the borders for communication. Instead they followed the majority's borders and agenda. The majority pupils expected the minority pupils to be homogenous when it came to language and behavior, in other words, they expected the minority pupils to assimilate.

Several of the minority pupils at Flata school were in fact integrated in the local society for example by taking part in sparetime activities, and they used the local places in the rural district such as the sports ground and the shops. The minority pupils were to a certain extent integrated at the school as well, but not necessarily integrated in the 
sense the majority pupils and partly also the teachers expected. For example they were integrated by taking part in the football games and other games in the breaks, by usually knowing how to behave inside during classes and in general knowing how the school day works.

By using football as a method to integrate the minority pupils, the focus was shifted from linguistic competence to playing, even though some pupils saw football as very serious and not as a game (see Connolly, 1998 : 85ff). Football is a universal phenomenon most children know and the intention was that this would create a sort of community within the classes when the classes play together. It was not a part of the plan that the World class pupils played with their own ball, this instead led to keeping up the distance.

At Flata School the teachers and headmaster were open to a multicultural policy. They wanted to see ethnic and cultural diversity as resources as opposed to problems (Staunæs, $2004: 342$ ), and they tried to implement plans to help creating a multicultural school such as through football or by teaching the majority pupils about different countries. It was, however, difficult to complete and keep these plans running with relatively few and continuously shifting minority pupils at the school and without real experience or the resources it takes. It was easy to overrun the minority pupils because of this, and the border between integration and assimilation became more blurred.

Moreover, the school was lacking mother tongue teachers for some of the minority pupils. It is a well-known fact that minority pupils who are not taught in their own mother tongue will have bigger problems learning the majority language (see for example : Holmen, 2002 ; Kulbrandstad, 1997 ; Pihl, 2005 ; Skoug and Sand, 2003 : 38ff ; Wikan, 2002 : 124 ; see also Seeberg, 2003 : 134ff). Lack of bilingual teaching in other subjects makes these pupils lag behind their class-mates in all the subjects. The teaching plan from 1987 (Mønsterplanen, 1987) had a multicultural goal, but the new current teaching plan from 1997 (L-97) has digressed from that and has a monocultural anchorage (id. ibid. : 47ff).

The focus on the ideology of likeness in the Norwegian schools put the teachers in a difficult situation because all the pupils were supposed to be treated equally but at the same time all the pupils had the right to adjusted teaching. The result was that the teachers reacted differently towards the minority - and majority pupils respectively and that the actions weren't always consistent. The teacher's experience and their anchorage in Norwegian culture make it a challenge to change this practice (Gilliam, 2004).

\section{Conclusions}

In Dal, spoken language was important for integration. But not just spoken language, it also had to be used in the right way and in all types of communication, i.e. body language, figures of speech etc. The World class was therefore important for the minority pupils as it was a safe place to learn language. Yet it was also segregating the minority and majority pupils physically and socially.

Furthermore, this study has shown that studies of integration and minority pupils based only on schools in Oslo or cityschools is not representative for the country as a whole. Geographical location has a very important impact both because of the number of minority pupils but also because of its local traditions, culture, nature, composition of inhabitants and trade and industry. Oslo has a much bigger number of immigrants from non-western countries than $\mathrm{Dal}$ and therefore more resources. Oslo has also of course in general a much bigger population density and the work sector in the two municipalities differs a lot. 


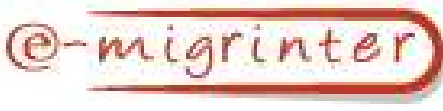

To understand which advantages and disadvantages "ghettoisation" and decentralizing have on integration requires several comparative studies on different places with different compositions of inhabitants and different local environments. Minority pupils in places with relatively few minority pupils will be more exposed to assimilation because one is isolated against a relatively bigger majority than minorities in Oslo for example. A minority pupil in Oslo will have a possibility to seek out pupils with the same mother tongue while this can be difficult or impossible in $\mathrm{Dal}$, since there may not be others with the same mother tongue. Instead one seeks out other minorities in general.

Thomas Hylland Eriksen suggested a different angle to the phenomenon of integration when he wrote in a debate in a Norwegian national newspaper that it is necessary to continue the discussion on how much and what the inhabitants in a country need to have in common for the support for the society's common institutions not to crumble. It is far from certain that immigrants diverge more than other people in the society. It can even be said that those who really need to be integrated is Progress party supporters ${ }^{10}$ or militant Christians or newly rich tax cheaters and not immigrants in general ${ }^{11}$ (Eriksen, 2005).

Ane Sætha University of Copenhagen, 2006 Master student asaetha@gmail.com

\footnotetext{
${ }^{10}$ Progress Party is an anti-immigrant populist party.

${ }^{11}$ My translation from Norwegian
}

Anderson, Sally (2000) I en klasse for sig, Copenhagen, Gyldendal Uddannelse, 267 p. (Socialpædagogisk bibliotek).

Barth, Fredrik (1998) [1969] Introduction, in Barth, Fredrik (ed.) Ethnic Groups and Boundaries, Long Grove (Illinois), Waveland Press, pp. 9-38.

Bostad, Finn (1998) Meningsskaping og medier, Trondheim (Norway), NTNU - Department of Language and Communication Studies, [réf. du 18.01.02] disponible sur internet: <http://www.hf.ntnu.no/anv/mellomfag/ HFAVS220/2001/160101/Meningsskaping. $\underline{\mathrm{htm}}>$

Bourdieu, Pierre (1986) The forms of capital, in Richardson, John G. (ed.) Handbook of theory and research for the sociology of education xxiv, Westport, Conn. Greenwood Press, pp. 241-258.

Bourdieu, Pierre (2003) [1994] Af praktiske grunde. Omkring teorien om menneskelig handlen, Copenhagen, Hans Reitzels Forlag, 243 p.

Bruner, Edward M. (1986) Experience and its expressions, in: Bruner, Edward M. ; Turner, Victor (ed.) The Anthropology of Experience, Urbana, University of Illinois Press, pp. 3-30.

Bundgaard, Helle ; Gulløv, Eva (2003) Sprog-lighed og Ulighed - om sociale forskelle $i$ en flerkulturel sammenhæng, Magasinet Humaniora, $\mathrm{n}^{\circ}$ 2, pp. 17-21.

Chandler, Daniel (2000) The transmission model of communication, [réf. du 17.01.02] disponible sur internet : $<\underline{\text { http://www.aber.ac.uk/media/Document }}$ s/short/trans.html $>$

Connolly, Paul (1998) Racism, Gender Identities and Young Children. Social relations in a multiethnic, inner-city primary school, London, Routledge, $214 \mathrm{p}$.

Duranti, Alessandro (2002) Linguistic Anthropology, Cambridge, Cambridge University Press, 493 p. 
Ejrnæs, Morten (2002) Etniske minoriteters tilpasning til livet i Danmark - forholdet mellem majoritetssamfundet og etniske minoriteter, Amid Working Paper Series, 18, [réf. du 16.09.05] disponible sur internet : <http://www.amid.dk/pub/papers/AMID 18-2002 Ejrnaes.pdf $>$

Emerek, Ruth (2003) Integration - eller inklusion ? Den danske diskussion om integration, Amid Working Paper Series, 31, [réf. du 29.04.04] disponible sur internet: $<$ http://www.amid.dk/pub/papers/AMID 31-2003 Emerek.pdf $>$

Eriksen, Thomas Hylland (2002) Ethnicity and nationalism. Anthropological perspectives, London, Pluto Press, 2nd edition, 199 p.

Eriksen, Thomas Hylland (2005) Visjonsløs bekymring, Dagbladet, 11.04, [réf. du 19.04.05] disponible sur internet : $<$ http://www.dagbladet.no/kultur/2005/04 L11/428472.html>

Gilliam, Laura (2004) Det er os der laver ballade. Etniske minoritetsbørns erfaringer i en københavnsk folkeskole, in Olwig, Karen Fog ; Valentin, Karen ; Gilliam, L. (ed.) Lokale hverdagsliv, fjerne forbindelser. Born og unge $i$ migrationsprocesser, Copenhagen, Hans Reitzels Forlag, pp. 57-77.

Gullestad, Marianne (2001) Likhetens grenser, in Lien, M. ; Lidén, H. ; Vike, H. (ed.) Likhetens paradokser. Antropologiske undersokelser $i$ det moderne Norge, Oslo, Universitetsforlaget, pp. 32-67.

Gullestad, Marianne (2002) Det norske sett med nye gyne, Oslo, Universitetsforlaget, $356 \mathrm{p}$.

Gulløv, Eva (1999) Betydningsdannelse blandt borm, Copenhagen, Gyldendal, 239 p.

Holmen, Anne (2002) Betydningen af sprog, tosprogethed og sprogligt bårne kulturformer for integrationsprocesserne, Amid Working Paper Series, 23, [réf. du 09.01.06] disponible sur internet : $<$ http://www.amid.dk/pub/papers/AMID 23-2002 Holmen.pdf>

James, Allison (1995) Talking of Children and Youth. Language, socialization and culture, in Wulff, H. ; Amit-Talai, V. (ed.) Youth cultures, London, Routledge, pp.43-62.

Kulbrandstad, Lars Anders (1997) Språkportretter. Studier av tolv minoritetselevers språkbruksmonstre, språkholdninger og språkferdigheter, Vallset, Oplandske Bokforlag, $160 \mathrm{p}$.

Kunnskapsdepartementet (1997) Om innvandring og det flerkulturelle Norge, Stortingsmelding 17, [réf. du 20.08.04] disponible sur internet : $<\underline{\text { http://odin.dep.no/krd/norsk/publ/stmel }}$ d/036005-040001/dok-bn.html>

Kunnskapsdepartementet

Morsmålsopplæring i grunnskolen, Stortingsmelding 25, [réf. du 16.09.05] disponible sur internet : $<$ http://odin.dep.no/ufd/norsk/dok/regpu bl/stmeld/014005-040020/dok-bn.html>

Kunnskapsdepartementet (2004) Kultur for læring, Stortingsmelding 30, [réf. du 20.08.04] disponible sur internet : <http://odin.dep.no/ufd/norsk/publ/stme ld/045001-040013/dok-bn.html>

Kunnskapsdepartementet (2004) Mangfold gjennom inkludering og deltakelse, Stortingsmelding 49, [réf. du 01.10.04] disponible sur internet: $<$ http://odin.dep.no/krd/norsk/dok/regpu bl/stmld/016001-040019/dok-bn.html>

Lidén, Hilde (2000) Barn - Tid - Rom Skiftende Posisjoner: Kulturelle lareprosesser $i$ et pluralistisk Norge, Trondheim, Faculty of Social Sciences and Technology Management - NTNU, 315 p. Th. Doct. : Trondheim : NTNU : 2000.

Lidén, Hilde (2001) Underforstått likhet. Skolens håndtering av forskjeller $\mathrm{i}$ et flerkulturelt samfunn, in Lien, M. ; Lidén, $H$. ; Vike, H. (ed.) Likhetens paradokser. Antropologiske undersokelser $i$ det moderne Norge, Oslo, Universitetsforlaget, pp. 68-85.

L-97, (1997) Lareplanverket for den 10-ärige grunnskolen [réf. du 20.08.04] disponible sur internet : < http://www.ls.no/L97/L97/> 
Moldenhawer, Bolette (2002) Skolen - en nøgle til integration af etniske minoritetsbørn?, Amid Working Paper Series, 25, 26 p. [réf. du 29.04.04] disponible sur internet :

$<\underline{\text { http://www.amid.dk/pub/papers/AMID }}$ 25-2002 Moldenhawer.pdf $>$

Moore, Alex (1993) Genre, Ethnocentricity and Bilingualism in the English Classroom, in Woods, Peter ; Hammersley, Martyn (ed.) Gender and Ethnicity in Schools. Ethnographic Accounts, London, Routledge, pp. 166-190.

Norsk Offentlig Utredning (1995) Opplaring $i$ et flerkulturelt Norge, 12, [réf. du 20.08.04] disponible sur internet : $<$ http://odin.dep.no/ufd/norsk/publ/utred ninger/NOU/014005-020001/dokbn.html>

Palludan, Charlotte (2002) Sproget er en del af spillet, Dansk Padagogisk. Tidsskrift, $\mathrm{n}^{\circ} 2$, pp. 74-81.

Pihl, Joron (2005) Etnisk mangfold $i$ skolen. Det sakkyndige blikket, Oslo, Universitetsforlaget, $260 \mathrm{p}$.

Preis, Ann-Belinda (ed.) (1998) Kan vi leve sammen? Integration mellem politik og praksis, Copenhagen, Munksgaard, 272 p. (Socialpædagogisk Bibliotek).

Qvortrup, Lars (2002) Det Hyperkomplekse Samfund. 14 fortallinger om informationssamfundet, Copenhagen, Gyldendal, 352 p.

Seeberg, Marie Louise (2003) Dealing with Difference: Two classrooms, two countries. Ph.d. thesis and NOVA-report, 18/03. Department of Social Anthropology, University of Bergen, Norway, 213 p.

Seeberg, Marie Louise (2004) Antropologer og multikulturalisme i Norge og andre steder, Norsk Antropologisk Tidsskrift, $\mathrm{n}^{\circ} 4$ (15), pp. 215-226.

Sjögren, Annick (1995) Minority Children in Majority Schools. Language and environment for children of the second generation, in Hjarnø, Jan (ed.) Multiculturalism in the Nordic Societies.
Proceedings of the $9^{\text {th }}$ Nordic seminar for Researchers on Migration and Ethnic Relations, Final report, pp. 314-321.

Sand, Sigrun ; Skoug, Tove (2003) Med Madhia og Akbar fra barnehage til skole. En oppfolging av prosjekt med gratis korttidsplass $i$ barnehage for alle 4-og 5-aringer $i$ bydel Gamle Oslo, Rapport 2, Oslo, Hedmark University College, $197 \mathrm{p}$.

Skovholm, Jens (1998) Flyktningene og velfærdsstaten, in Preis, Ann-Belinda (ed.) Kan vi leve sammen? Integration mellem politik og praksis., Copenhagen, Munksgaard, (Socialpædagogisk Bibliotek).

Skutnabb-Kangas, Tove (1986) Minoritet, språk och rasism, Stockholm, Liber, 214 p.

Staunæs, Dorte (2004) Kon, etnicitet og skoleliv, Fredriksberg, Forlaget Samfundslitteratur, $372 \mathrm{p}$.

Sætha, Ane (2006) Integrasjon og kommunikasjon, Copenhagen, Department of Anthropology, University of Copenhagen, $94 \mathrm{p}$.

Mém. Master : Antropology : Copenhagen : 2006.

Thorseth, May (ed.) (1995) Norskopplaring som virkemiddel $i$ integreringsarbeidet? En evaluering av dagens kvalifiseringsordninger for fremmedspråklige, Sintef Trondheim, Tapir Trykk, 200 p.

Turner, Terence (1993) Anthropology and multiculturalism: What is anthropology that multiculturalists should be mindful of it?, Cultural Anthropology, 8 (4), pp. 411-429.

Wikan, Unni (1993) Beyond the words: the power of resonance, in Palsson, G. (ed.) Beyond boundaries. Understanding, translation and anthropological discourse, Oxford, Berg, pp. 184-209.

Wikan, Unni (2002) Generous betrayal. Politics of culture in the new Europe, Chicago, The University of Chicago Press, 293 p. 